\title{
EVIDENCE BASED APPROACH TO RECURRENT MISCARNAGE
}

\author{
Ayse SEYHAN', Baris ATA², Bulent URMAN' \\ ${ }^{1}$ Amerikan Hastanesi Kadın Sağlığı Merkezi, Üremeye Yardımcı Teknolojiler Ünitesi, İstanbul \\ 2 McGill Üniversitesi, Kadın Hastalıkları ve Doğum Anabilim Dalı, \\ Reprodüktif Endokrinoloji ve İnfertilite, Montreal, Kanada
}

\begin{abstract}
SUMMARY
Recurrent miscarriage, defined as three or more consecutive misscarriages, affects approximately 0.5-1\% of couples trying to have a child. Genetic and uterine abnormalities, thrombophilias, environmental, endocrinologic and immunologic factors have been proposed to play a role in the etiology of recurrent miscarriage. The underlying pathology remains unidentified in approximately half of the recurrent miscarriage patients. Couples' expectations for a treatment often causes physicians to employ empiric treatments. In this review we will discuss the prognosis and evidence-based aproach to diagnosis and treatment of recurrent miscarriage.
\end{abstract}

Key words: early pregnancy loss, recurrent miscarriage, recurrent pregnancy loss, spontaneous abortion

Journal of Turkish Society of Obstetrics and Gynecology, (J Turk Soc Obstet Gynecol), 2011; Vol: 8 Issue: 1 Pages: 5 - 20

\section{TEKRARLAYAN GEBELİK KAYIPLARINA KANITA DAYALI YAKLAȘIM}

\section{ÖZET}

Gebelik planlayan kadınların yaklaşık \% 0.5-1 ’i üç veya daha fazla ardışık gebelik kaybı yaşamaktadır. Etyolojide genetik anormallikler, uterin patolojiler, trombofili, çevresel faktörler, endokrinolojik ve immünulojik nedenler rol oynayabilir. Tüm bu faktörler araştırılsa da hastaların yaklaşık yarısında herhangi bir neden ortaya konulamamaktadır. Açılanamayan tekrarlayan gebelik kayıpları olan hastalar tedavi beklentisi içinde olduğundan, hekimler ampirik tedavi alternatiflerine sık sık başvurmaktadır. Bu derlemede, tekrarlayan gebelik kayıplarının prognozu, tanı ve tedavi yöntemleri mevcut kanıtlar ışığında tartışılacaktır.

Anahtar kelimeler: düşük, tekrarlayan gebelik kaybı

Türk Jinekoloji ve Obstetrik Derneği Dergisi, (J Turk Soc Obstet Gynecol), 2011; Cilt: 8 Sayl: 1 Sayfa: 5 - 20

Address for Correspondence: Uzm. Dr. Barış Ata. Güzelbahçe sokak no: 20 Nişantaşı, 34365 İstanbul Phonel.: +90 (0532) 7447416

e-mail: barisata@hotmail.com

Received: 16 October 2009, revised: 03 February 2010, accepted: 28 March 2010, online publication: 15 December 2010 


\section{DESCRIPTION AND INCIDENCE}

Recurrent pregnancy loss (RPL) is described as $\geq 3$ consecutive pregnancies with the same partner, which end in spontaneous abortion before the twentieth gestational week $^{(1,2)}$. Ten to twenty percent of women experience a miscarriage throughout their reproductive period, $2 \%$ have two consecutive abortions and 0.5 $1 \%$ of them have three consecutive abortions ${ }^{(3-5)}$.

Primary RPL is described as $\geq 3$ consecutive pregnancy losses occurring before the twentieth gestational week in the absence of a previous delivery. Secondary RPL is described as RPL following a pregnancy resulting in live birth, stillbirth or neonatal death after the twentieth gestational week.

The etiology of miscarriage and the prognosis are thought to vary with regard to the period when miscarriage occurred during pregnancy, it has been suggested to categorize pregnancy losses as: pre- embryonic for miscarriages before five weeks, embryonic for five to ten weeks, and fetal loss for ten weeks onwards ${ }^{(5)}$.

\section{PROGNOSTIC FACTORS}

\section{Number of previous pregnancy losses}

The number of previous pregnancy losses is one of the most important prognostic factors for RPL cases. The probability of the next pregnancy ending in a fullterm live birth decreases as the number of previous miscarriages increases. The probability of a live birth subsequent to one miscarriage is $80 \%$, and it is $70-80$ $\%, 50-60 \%, 45 \%, 41 \%$ and $13 \%$ subsequent to $2,3,4$, 5 and 6 consecutive pregnancy losses, respectively $(6)$.

\section{Maternal age}

When women with recurrent pregnancy loss are categorized by their ages, the probability of the next pregnancy ending in miscarriage is similar between the 30-34 years and the 35-39 years groups, and the risk rises dramatically to $70 \%$ for the $40-44$ years group ${ }^{(3)}$.

\section{Prior live birth}

It has been reported that the chances of having a live birth differ between women who had four consecutive pregnancy losses subsequent to one live birth in her first pregnancy and women who had a live birth in her second pregnancy following a miscarriage in the first and then had three consecutive pregnancy $\operatorname{losses}^{(7)}$. It was reported that the patient group in the first scenario had a worse prognosis than the group in the second scenario. This study supports the concept that secondary RPL is not coincidental but some risk factors developed during the first pregnancy which results in a live birth. It is suggested that the gender of the first infant has an effect on the prognosis in patients with secondary RPL (8). The probability of achieving a live birth following secondary RM was calculated to be $58 \%$, when a boy was delivered in the first pregnancy and the same probability was found to be $76 \%$ for women who delivered a girl in the first pregnancy. Therefore; the firstborn infant being male is regarded as a negative prognostic factor. The development of an immune response against male specific minor histocompatibility antigens was suggested as a probable mechanism.

\section{The timing of previous pregnancy losses}

It has been reported that women with recurrent pregnancy loss during pre-embryonic or embryonic period have a better prognosis than women with recurrent fetal losses ${ }^{(9,10)}$. While the chance of a live birth is about $70 \%$ following early RM, pregnancy loss between 16-27th gestational weeks increase the risk of recurrence by 20 fold and the risk of fetal death after 28th gestational week by five fold $(10,11)$

\section{The chromosomal constitution of products of conception}

An aneuploid miscarriage is considered to be a positive prognostic factor. The presence of aneuploidy suggests that the miscarriage has occurred due to a fetal cause and prognosis can be favorable because the probability of having a euploid embryo in the next pregnancy is high. The probability of a live birth is reported to be $41 \%$ for a pregnancy subsequent to a euploid miscarriage and while it is $68 \%$ subsequent to an aneuploid miscarriage(2).

\section{FACTORS WHICH ARE CONSIDERED TO PLAY A ROLE IN THE ETIOLOGY}

\section{The coagulation system \\ Thrombophilia}

Hypercoagulability occurs in pregnancy as a result of physiological changes such as decreased protein- $\mathrm{C}$ 
levels, the formation of resistance against the activated protein- $\mathrm{C}$, increased clotting factors, and deteriorated fibrinolysis $(13,14)$. Thrombophilia is a group of conditions in which the risk of venous thrombosis is increased, and can be classified as hereditary and acquired thrombophilia. Thrombophilia is thought to play a role in RPL, as obstetric complications such as uteroplacental insufficiency and fetal losses are more frequent in patients with thrombophilia due to the development of placental infarcts subsequent to the thrombosis in decidual blood vessels ${ }^{(15-18)}$. Factor V Leiden mutation, prothrombin G20210A mutation and MTHFR gene mutations (677 and 1298 mutations), and protein $\mathrm{C}$, protein $\mathrm{S}$ and antithrombin deficiencies can be included in hereditary thrombophilia group. The first trimester losses are not expected theoretically in patients with inherited thrombophilia, as the placental circulation does not develop exactly during the first trimester. However, some suggest that there is a relationship between hereditary thrombophilia and early pregnancy losses and RPL (19-23). In some studies, early pregnancy losses have been reported to be less frequent in carriers of thrombophilic mutation(24-27). This discrepancy may be coincidental as well as due to the differences in the study designs. It should be noted that even the definitions of RPL used differ between studies. While RPL is defined as two or more consecutive pregnancy losses in some studies, the pregnancy losses up to 28th week of the pregnancy are also included in the definition of RPL in some studies. Inclusion and exclusion criteria are highly variable between the studies. Thrombophilia screening in clinical practice is still a controversial practice due to the conflicting results of studies showing the relationship between inherited thrombophilia and recurrent pregnancy los. Moreover there is no evidence to recommend anti-thrombotic therapies due to lack of placebo-controlled randomized trials.

\section{Antiphospholipid syndrome}

There is a consensus regarding that antiphospholipid syndrome (APS), which is a typical example of acquired thrombophilia, causes RPL. All pregnant women, who have a history of three or more pregnancy losses prior to 10 weeks' gestation, one or more morphologically normal pregnancy losses after the 10th week of gestation or pre-eclampsia prior to 34 weeks' gestation during one or more pregnancy, and premature delivery due to the placental insufficiency, should be investigated for the $\operatorname{AFS}^{(28)}$. Miscarriage is considered to be deterioration of the fetoplacental circulation due to thrombosis formation and affected trophoblast functions in maternal decidua and intervillous space. Prostacyclin-thromboxane imbalance, increased expression of tissue factor, protein $\mathrm{C}$ activation, inhibition of activated protein $\mathrm{C}$ function are other possible mechanisms ${ }^{(29-32)}$. Antiphospholipid antibodies increase the aggregation of platelets and the interaction of platelets with endothelium. The expression of Annexin $\mathrm{V}$ that creates a protective antithrombotic shield on trophoblasts was found to be decreased in patients with $\operatorname{APS}(33,34)$.

Antiphospholipid antibodies (aPL) are divided into two main groups as aPL antibodies prolonging and not prolonging phospholipid-dependent clotting assays. The levels of the anti-cardiolipin (aCL), antiphosphatidylethanolamine (aPE), antiphosphatidylserine (aPS), anti-phosphatidylcholine (aPC), anti-phosphatidylglycerol (aPG), antiphosphatidylinositol (aPI), anti-phosphatidic acid (aPA) antibodies and B2-glycoprotein I (a B2-GPI), which are APL antibodies those do not prolong phospholipiddependent coagulation tests are measured quantitatively or semi-quantitatively. The results are expressed in aPL units, and one unit is equivalent to the binding capacity of $1 \mathrm{mg} / \mathrm{ml}$ pure phospholipid. The measurement is carried out in GPL (IgG), MPL (Ig M) and APL (IgA) units depending on the immunoglobulin isotype ${ }^{(35)}$. At least two of dilute Russell's viper venom time (dRVVT), kaolin clotting time, dilute prothrombin time, textarin time or taipan time tests should be used for the detection of lupus anticoagulants (LA) that prolongs phospholipiddependent coagulation tests ${ }^{(36)}$. The test result is positive or negative for $\mathrm{LA}^{(37)}$. Classically, positive LA test result and/or aCL IgG level of $>20 \mathrm{GPL} u / \mathrm{ml}$ and/or aCL IgM level of $>20 \mathrm{MPL} \mathrm{u} / \mathrm{ml}$ aPL is considered to be sufficient for the diagnosis of miscarriage due to aPLs. As APLs may be transiently detected in normal individuals, the test is recommended to be repeated at six-week intervals ${ }^{(38-41)}$. APL tests should be done during pregnancy or at a time close to the pregnancy loss, because these tests tend to fall after the termination of pathologic pregnancies(37).

While aCL, APE and aPS cause thrombosis in placental blood vessels by targeting phospholipids in endothelial 
cells, it has been suggested that aPE and aPS also cause trophoblast dysfunction by targeting phospholipids in trophoblasts. Furthermore aPC, aPG, and the aPI affects the embryogenesis phase by targeting phospholipids in the pre-embryonic tissue ${ }^{(38)}$. LA and aCL are most frequently used in clinical practice. When the histological examination of the placenta demonstrates thrombosis it is recommended to test for aPLs that affect the endothelium, and to test for aPLs that affect trophoblasts and implantation for women who had pre-embryonic and early pregnancy losses ${ }^{(35)}$.

Antibody titers and the number of positive aPL test results were found to be associated with clinical results $(42,43)$. While aCL and/or other aPL levels of $>40 \mathrm{GPL}$ $\mathrm{u} / \mathrm{ml}$ indicate that pharmacological treatment can be beneficial for the subsequent pregnancy, aCL levels of $>80 \mathrm{GPL} \mathrm{u} / \mathrm{ml}$ indicate a high risk of fetal death for the subsequent pregnancy(42). More than one positive test result for aPL is a more reliable variable to predict pregnancy loss than one positive test result for aPL ${ }^{(43)}$. A positive test result for aCL before pregnancy or an increase in the titration level during pregnancy is one of the poor prognostic factors $(44)$. The chance of the live birth is reduced by 36 to $48 \%$ in patients with aCL in the absence of LA compared with women who are negative for both aCL and $\mathrm{LA}^{(45)}$.

Low-dose aspirin, heparin, intravenous immunoglobulin (IVIG), glucocorticoids, and their combinations are proposed for the prevention of pregnancy losses in patients with APS. Aspirin is thought to reduce pregnancy losses by blocking cyclo-oxygenase and thromboxane synthesis in platelets, by providing anticoagulation, and stimulating the low levels of IL3 in patients with APS(46-48). In addition to the antiinflammatory effects of heparin, it acts by binding antiphospholipid antibodies and protecting trophoblast phospholipids, by preventing adhesion of leukocytes to the endothelium, and by inhibiting the coagulation. Trials in RPL patients with APS, comparing aspirin with placebo showed no significant effect on livebirth rate $^{(49-51)}$, while the combination of aspirin and heparin was found to reduce pregnancy loss by $54 \%(52)$. Although there is a consensus about the concomitant use of heparin and aspirin in the treatment of APS, in or opinion, it is still unclear whether the aspirin component of the treatment is beneficial.

It has been reported that, the use of glucocorticoid alone or its combined use with other therapeutic agents has no effect on the treatment of RPL, as well as it has possible side effects such as gestational diabetes, hypertension, pre-eclampsia, infection and osteoporosis $(53,54)$

In the treatment of APS secondary to systemic lupus erythematosus (SLE), it is recommended to use the lowest dose of glucocorticoid that controls $\operatorname{SLE}^{(35)}$.

IVIG is thought to be useful in RPL cases with APS by inhibiting aCL and LA, increasing antibody clearance and providing a reduction in the production of $\mathrm{aCL}$ via B-cell antigen receptors. However, IVIG has been reported to increase the risk of pregnancy losses and preterm birth in the meta-analysis of studies on IVIG use in women with $\operatorname{APS}(52)$.

The management of patients with positive antiphospholipid antibodies, and with pregnancy loss without a history of thrombosis is controversial. The treatment with the low-dose aspirin (75 mg/day) and prophylactic doses of unfractionated heparin or low molecular weight heparin (enoxaparin $1 \mathrm{mg} / \mathrm{kg} /$ day) has been reported to be effective on patients with three or more pregnancy losses before 10th week of pregnancy $(55>56)$. Low-dose aspirin and full therapeutic dose of unfractionated heparin or low molecular weight heparin (enoxaparin $1 \mathrm{mg} / \mathrm{kg}$ every 12 hours) have been found to be useful in the management of APS cases with a history of thrombosis or one or more fetal loss after 10th gestational week $(56,57)$. Low-molecular-weight heparin is more preferable than unfractionated heparin because of both its side-effect profile and its lesser injection volumes providing the same effectiveness.

\section{Endocrinological factors}

Luteal phase defect

The human embryo reaches the uterine cavity 4 days after ovulation, and implantation occurs approximately 7 days after ovulation, or 19-24 days after the last menstrual period(58). The rate of early pregnancy loss has been reported to be increased with increasing interval between ovulation and implantation (59). 17.4 to $28 \%$ of cases of recurrent pregnancy loss have been reported to have luteal phase defect (LPD) $(60,61)$. The delay in endometrial growth and maturation due to insufficient secretion of progesterone in the corpus luteum is thought to be associated with early pregnancy loss. LPD is assessed by histological evaluation of endometrium or by measuring 
progesterone level in luteal phase. However, inter/intraobserver and inter-cycle variability of pathological examination of the endometrium is high. For example, in a study in which the same sample was evaluated by the same pathologist at two different times, exact agreement occurred in $24 \%$. In a separate part of the study, the patients underwent endometrial biopsy two times in different cycles, and exact agreement in the diagnoses was found to be only $4 \%(62) .26 .7 \%$ of the of regularly menstruating women of proven fertility was reported to have LFD diagnosed by endometrial biopsy ${ }^{(63)}$. In conclusion, the reliability of the diagnosis of LPD based on the histological evaluation of the endometrium is poor. Mid-luteal progesterone levels of $<10 \mathrm{ng} / \mathrm{ml}$ is considered as the threshold for the diagnosis of LPD. Progesterone levels of all women were found to be in normal limits in a study measuring progesterone levels of the patients diagnosed with LPD by endometrial biopsy(61). In another study comparing patients with and without LPD by their progesterone levels, luteal phase progesterone levels were found to have no predictive value for future pregnancy losses ${ }^{(64)}$. LPD, in our opinion, should be treated as a separate clinical entity due to both the controversies in the diagnostic criteria for LPD and the lack of strong evidence about its role in the etiology of RPL. Invasive and expensive tests should be avoided for the diagnosis of LPD.

\section{Hypothyroidism}

Although hypothyroidism is not a common condition in patients with RPL, it is recommended to include the TSH testing in routine investigation. Maternal hypothyroidism has negative effects on fetal development and TSH measurement is an easy test providing accurate results ${ }^{(65-67)}$.

\section{Diabetes Mellitus}

The diabetic patients with good glycemic control are not at risk for RPL (66). Pre-pregnancy hemoglobin A1c levels of $7.5 \%$ or less substantially reduces the risk of pregnancy loss ${ }^{(68)}$. It is obvious that pre-pregnancy optimization of the glycemic control will be beneficial for the health of the mother and fetus, even though it is considered to not make a difference for RPL.

\section{Polycystic ovary syndrome}

Patients with polycystic ovary syndrome (PCOS) have an increased risk of pregnancy loss ${ }^{(69)}$. This increase is thought to be due to higher levels of $\mathrm{LH}$ and testosterone, and insulin resistance. Although its mechanism could not be fully elucidated, obesity has been reported to increase the incidence of first trimester pregnancy losses and RPL ${ }^{(70)}$. A negative correlation has been reported between body mass index (BMI) and Leukemia Inhibitory Factor (LIF), which is thought to have an important role in the implantation(71). As about half of patients with PCOS are overweight or obese, increased incidence of miscarriage in this patient group may be associated with obesity. The weight loss should be presented as an option to these patients.

\section{Progesterone}

Progesterone is secreted in the corpus luteum under the influence of hCG and creates the secretory changes that are required for the continuation of implantation and pregnancy in endometrium ${ }^{(72)}$. Csapo demonstrated in his classical study that luteoectomy performed before the 8 th gestational week had resulted in the miscarriage ${ }^{(73)}$.

Progesterone is widely used in threatened abortion cases because of its immunomodulatory and antiabortive effects. However, in meta-analysis of studies on progesterone use in pregnant women with threatened abortion, no positive effect of progesterone was found irrespective of the dosage and administration, however in the subgroup analysis of patients with RP, it has been reported to be effective in reducing the incidence of pregnancy losses ${ }^{(74)}$. But the power and reliability of the studies are poor due to small sample size, variation in treatment protocols and definitions of RPL, inclusion of older age groups. Moreover, the vast majority of studies were not placebo-controlled. Welldesigned, large-sampled, randomized controlled trials are needed to recommend progesterone therapy routinely to these patients.

There are studies reporting that the use of progesterone increases the risk of hypospadias $(75,76)$. Therefore, the potential teratogenic effects of maternal progesterone therapy should not be ignored.

\section{Chorionic Gonadotropin}

Human chorionic gonadotropin (hCG), allows the survival of the corpus luteum in early pregnancy. hCG levels and consequently progesterone levels decrease in pregnancies that could not continue its normal development. The meta-analysis of the trials of the use of hCG in the management of RPL showed a significant reduction in 
the risk of the miscarriage (Odds Ratio: $0.26,95 \%$ confidence interval: 0.14 to 0.52$)^{(77)}$. Some of these studies were not placebo controlled and no information was given about randomization. In the conclusion section of metaanalysis, it was emphasized that the data was insufficient and not convincing for the routine use of $\mathrm{hCG}$ in clinical practice due to the methodological weaknesses of the studies. In a randomized placebo-controlled, double-blind study, which was included in meta-analysis, hCG was reported to be beneficial in only a subgroup of patients with history of oligomenorrhea (Odds Ratio: $0.15,95 \%$ confidence interval: (0.03-0.83).

\section{Immunological factors}

The rejection of the embryo as a result of a defect in the maternal immune tolerance against semi-allogenic fetus is thought to be another mechanism that can play a role in the etiology of RPL. The role of the number/ activity of NK cells has also been studied as well as the role of the increased sharing of human leukocyte antigens (HLA) between the couples, and molecular immunosuppressive factors such as cytokines and growth factors that are secreted at the level of local decidual trophoblasts(78-81).

The relationship between the increase of HLA sharing between the couples and the prognosis of subsequent pregnancies could not be detected(82-85). Classical HLA class I and II antigens other than HLA C antigen were not expressed in early embryos and trophoblasts $(86,87)$. HLA-G is the HLA type existing abundantly in maternalfetal interface ${ }^{(88)}$. NK cells has the potential to destroy cytotrophablasts by recognizing the cells that are not classical major histocompatibility (MHC) I molecules. HLA $G$ has been suggested to have inhibitory effects on NK cells ${ }^{(89)}$. Although HLA-G polymorphism in RPL cases was investigated and some of the HLA-G alleles have been reported to be associated with RPL, this relationship could not been confirmed in later studies(90-92). It has been suggested that there may be a relationship between maternal HLA DR1 and DR3 antigens and RPL(93). TNF-a gene is associated with HLA-DR, and RPL is thought to occur due to a predisposition to hypersecretion of TNF-a ${ }^{(94)}$.

The expression of the Th2-dependent anti-inflammatory cytokines (IL-3, IL-4, IL-5, IL-6, IL-10, IL-13) is increased compared to that of the Th1 dependent proinflammatory cytokines (TNFa, IFNg, IL-2, IL-12, IL18) ${ }^{(95)}$ during pregnancy. While Th2-dependent cytokine production is more dominant in normal pregnancy, the risk of abnormal development of placenta and embryo and fetal loss has been suggested to be increased under the influence ofTH1-dependent cytokines preponderance (96-98). Th1 cytokine response was increased in patients with RPL and recurrent implantation failure ${ }^{(99)}$. Th1dependent cytokines are thought to harm the pregnancy by inducing hypercoagulability.

Exposure to semiallogenic embryogenic antigens increases the number of intracellular progesterone receptors (PR) in the endometrium ${ }^{(100)}$. Activated maternal lymphocytes produce a protein called progesterone-induced blocking factor (PIBF) in the presence of progesterone ${ }^{(101-102)}$. PIBF increases the production of IL-4, IL-6 and IL-10 by changing Thl/Th2 ratio in favor of Th2(103-105). A positive feed-back mechanism is created by inducing the release of hCG by IL-4 and IL- 6 in trophoblasts, followed by the stimulation production of progesterone by hCG and secretion of Th 2 cytokines by progesterone. Type of the cytokine predominance during antigen presentation in fetomaternal microenvironment is thought to be important for the determination of the dominance of Th1 or Th2 and therefore for a successful pregnancy . Decidual natural killer (NK) cells have been suggested to control trophoblast invasion via the immunomodulatory cytokines and angiogenic factors ${ }^{(106)}$. NK cells have been reported to be increased in endometrium of patients, who had recurrent pregnancy loss ${ }^{(107-109)}$. It is suggested that increased number and activity of NK cells will cause the stimulation of the secretion of inflammatory cytokines in Th1 cells, the production of TNF-a and nitric oxide with decidual macrophage activation via IFN-g, and therefore a damage to conceptus via apoptosis $(96,110-112)$. However, studies investigating the effect of the number of NK cells on RPL cases have conflicting results $(107,108,113-117)$.

In a study on rodents, it was detected that the subjects that had no NK cells developed placental hypertrophy and consequently fetal death occurred, and therefore the positive role of NK cells for the continuation of pregnancy has been proven ${ }^{(118)}$. However, a strong correlation between the number and activity of NK cells and pregnancy outcome could not be demonstrated. On the other hand, progesterone has been suggested to suppress the activity of NK cells via PIBF and prevent rejection of the embryo by increasing the production of asymmetric antibodies in B lymphocytes (119-121).

Although the alloimmune causes of recurrent pregnancy 
loss have not been fully elucidated and proved, a variety of immunological treatments are being tested. Immunomodulatory therapies are being tested especially in patients with unexplained RPL, by considering that this condition is due to immunological problems, which disrupt normal placentation but have not been identified yet. The most commonly applied therapies are paternal leukocyte immunization and intravenous immunoglobulin (IVIG) therapy.

Paternal leukocyte immunization has been suggested to act by induction of paternally derived fetal antigens to reinforce maternal Tcells to stimulate anti-T cell receptor idiopathic antibody (anti-TCR) formation thus regulate the maternal response to the fetus(122-124). It is also suggested that paternal leukocyte immunization suppress Th1 cytokines and reduce the activity of NK cells by enhancing asymmetric antibodies against $\mathrm{R} 80 \mathrm{~K}$ antigens, which are recognized by NK cells on the surface of trophoblast (L25). All of these theories comply very poorly with the clinical outcome. In meta-analysis of 12 randomized controlled trials about paternal leukocytes iso-immunization and RPL, this treatment has been shown to have no clinical impact (126).

IVIG therapy has been reported to suppress in vitro production of pro-inflammatory cytokines and decrease the number/activity of NK cells ${ }^{(127,128)}$. It has been suggested that IVIG neutralizes pathologic antibodies by interacting with their Fc portions or passively via anti-idiotypic antibodies $(129,130)$. In addition, IVIG has been shown to create anti-inflammatory effects by inhibiting the complement system in animal studies $(131,132)$. IVIG as a treatment in RPL patients has not been shown to be of benefit in terms of live birth rates in meta-analysis of 8 randomized controlled trials ${ }^{(126)}$. Nephrotoxicity, alopecia, aseptic meningitis, retinal necrosis, thrombosis, ischemic heart disease and cerebrovascular events have been reported after IVIG treatment in the literature ${ }^{(133)}$. In the view of all of these information, we believe that immunotherapy remain experimental and should not be offered as a treatment for RPL cases, outside the research context.

\section{GENETIC FACTORS}

\section{Parental karyotype}

Balanced translocation has been identified in 3 to $5 \%$ of couples, who experience RPL $(134,135)$. Although these individuals have no chromosomal material loss or duplication in their own somatic cells and are phenotypically normal, meiotic segregation in haploid gonadal cells results in duplication or lack of genetic material. $60 \%$ of balanced translocations are reciprocal translocations that are formed by exchange of segments between two non-homologous chromosomes, and 40\% are Robertsonian translocations that are formed by the fusion of two acrocentric chromosomes at centromere with the loss of short arms. Boue and Gallano carried out a collaborative study involving 71 European prenatal diagnosis centres on the karyotype of fetuses of 1356 couples in which a parent was detected to have balanced structural chromosomal abnormalities. It has been reported that abnormal chromosomes were transferred to $40 \%$ of fetuses ${ }^{(136)}$.In other words, $60 \%$ of fetuses whose parents have balanced translocation have euploid chromosomal constitution. The live birth rates in untreated RPL cases are about 60\%. Carp et al evaluated chromosomal structure of 1108 couples, who had RPL, and chromosomal structure of subsequent abortion materials of these couples.

The most common chromosomal abnormality detected was balanced translocation, followed by inversions in RPL couples.

Aneuploidy was identified in $30.8 \%$ of fetal karyotypes in parents with parental chromosomal anomalies, and in $23.2 \%$ of fetal karyotypes of couples with no parental chromosomal aberrations, and the difference was not statistically significant ${ }^{(137)}$. The same team conducted another study and evaluated the karyotypes of 916 couples who had RPL, the live birth rate was found to be decreased from $55.3 \%$ to $45.2 \%$ in the presence of a parental chromosomal anomaly. This difference was not also statistically significant ${ }^{(138)}$. In the study of Clifford et al, $38 \%$ of couples with RPL and chromosomal abnormality was reported to have a successful pregnancy in the past ${ }^{(66)}$. The number of previous pregnancy losses, maternal age and chromosomal structure of previous pregnancy product appear to be more effective than parental chromosomal structure for the prognosis of subsequent pregnancy in RPL patients.

Although it is difficult to assume that RPL is only due to the unbalanced transfer of chromosomal aberrations in couples with parental karyotype abnormality, assessment an existing genetic problem will be beneficial in terms of clarifying the etiology and informing the couples about which risks other than 
pregnancy loss are associated with the genetic problem that they are carrying. American College of Obstetricians and Gynecologists of (ACOG), the Royal College of Obstetricians and Gynecologists (RCOG) and the European Society of Human Reproduction and Embryology recommend carrying out parental karyotyping routinely in the evaluation of RPL $(65,139,140)$. Parental karyotyping is more affordable in our country compared to both North America and European countries in terms of cost and, offering parental karyotyping to RPL couples and consulting a clinical geneticist in case of detection of an abnormality seem to be the most appropriate approach. It should be kept in mind that that couples, who had a high number of pregnancy losses, even if not consecutive, may have genetic problems, because pregnancies of translocation carrier couples may also achieve successful live births.

\section{Cytogenetic Analysis of Abortion Material}

Although recurrent aneuploidies considered to be one of the causes of RPL, and 16\% of pregnancy loss products following aneuploid abortion were detected to have aneuploidy, and this risk was not different from the initial risk of aneuploid abortion (15\%) of all pregnant women ${ }^{(141)}$.

Trisomies are the most frequently detected chromosomal abnormalities in abortion materials in recurrent pregnancy losses and aberrations of $21 \mathrm{st}$, 16 th and 18th chromosomes were the most prevalent anomalies ${ }^{(12)}$

Although the frequency of aneuploidy has been suggested to be increased in RPL cases ${ }^{(142,143)}$, the frequency of aneuploidy was reported to be similar or even lower in patients with RPL compared to controls $(144-146)$.

While RCOG has recommended routine karyotyping of abortus material for the evaluation of RPL, ACOG guideline states that a definitive recommendation for routinely obtaining abortus karyotypes cannot be made (147). As a result of the joint working party of RCOG (140) and the Royal College of Pathologists, they recommend to take the tissue sample with hysteroscopy for fetal karytotyping and to examine samples of placenta and full-thickness skin in order to overcome problems such as maternal cell contamination and lack of reproduction in cell culture ${ }^{(148)}$.

In summary, detection of fetal aneuploidy indicates that abortion has a fetal origin and subsequent pregnancies may have a higher likelihood of live birth. While live birth rates of subsequent pregnancy were found to range from 62 to $67 \%$ in the case of the detection of aneuploidy in abortion material, these rates were found to range from 37 to $38 \%$ in the case of the detection of euploidy(12,146). The role and the psychological benefit of the assessment of the chromosomal structure of abortus material in informing the family about prognosis are invaluable. To overcome the above-mentioned technical obstacles, it would be accurate to consult the genetic laboratory for the proper sampling and delivery to the laboratory.

\section{Preimplantation genetic screening (PGS)}

Chromosome abnormalities have been identified in $50-70 \%$ of spontaneous abortions ${ }^{(149-151)}$. Considering that 10 to $15 \%$ of clinically detected pregnancies end with spontaneous abortions, 5 to $10 \%$ of pregnancies result in sporadic abortions due to chromosomal abnormalities. Recurrent pregnancy loss is seen in $1 \%$ of the population, and this rate is higher than the rate that can be associated with recurrent aneuploidy $(0.15 \times 0.15 \times 0.15=0.0034)$.

In the studies of Ogasawara and Stern including patients, who had two or more pregnancy losses, the rate of aneuploidy was found to range from 50 to $60 \%(146,152)$. Ferro et al demonstrated aneuploidy in $67 \%$ e of biopsies of chorionic and embryonic tissues in abortus material which were obtained by hysteroembryoscopy. ${ }^{(153)}$. Carp and colleagues have found the frequency of chromosomal abnormalities as $29 \%$ in abortion materials of 125 RPL cases of which had the classical definition of RPL (12). A negative correlation between the number of abortion and the incidence of chromosomal abnormalities has been reported ${ }^{(146)}$. The frequency of karyotype abnormalities in subsequent abortion materials was found to be $59.4 \%$ in women with previous three abortions, $55.5 \%$ in women with previous four abortions, $39.6 \%$ in women with previous five abortions, and $28 \%$ in women with previous six abortions ${ }^{(146)}$.

It was considered that implantation rates can be increased and abortion rates can be decreased by enhanced embryo selection with normal karyotypes by PGSRubio et al have reported live birth rate of $83 \%$ with PGS in patients with two or more pregnancy losses (mean pregnancy loss = $2.9)^{(154)}$. However, control group in this study included patients without a history of RPL and it is not appropriate to compare the results with this group. In addition, it is 
possible thatthe results of the study to have been influenced by the number of previous pregnancy losses.BAs mentioned above the incidence of chromosomal abnormalities is lower in subsequent pregnancies of RPL cases with three or more pregnancy losses. Another study statedg that pregnancy rate increases with PGS in RPL cases, however it was reported that, while PGS was beneficiall in women over 35 years old, the results were disappointing in women aged 35 years and under (155). This study did not include a control group, and the birth rate was compared with hypothetical birth rates calculated according to a formula with the main determinants of maternal age and previous pregnancy loss. Considering the fact that RPL patients don't have infertility issues thus high pregnancy rates are expected following IVF treatment. In the study of Plateau et al, ongoing pregnancy rate was $29 \%$ inyoung RPL cases (less than 37 years old)undergoind PGS. Live birth rates of $>60 \%$ can be expected in this patient groupjust with expectant management. All of the studies in the literature regarding PGS in RPL patients are observational studies and there are no randomized controlled trials (L56).

It is not possible even for the most experienced hands to correctly perform blastomere biopsy, nuclear fixation and FISH analysis, which are the important stages of PGS. Accuracy rate of FISH analysis per probe ranges from 92 to $99 \%$. Therefore, the use of multiple probes increases the possibility of misdiagnosis $(157,158)$. Mosaicism is a common condition in human pre-implantation $\operatorname{embryos}^{(159,160)}$. Aspiration of normal blastomere reduces the rate of diploid blastomeres in diploid-aneuploid mosaicism and lead to transfer of an embryo with an increased proportion of of abnormal cells. On the other hand, aspiration of aneuploid blastomere results in the discarding the embryo by considering it as aneuploid, despite the fact that the procedure actually increased the proportion of normal blastomeres and the embryo has the viability potential.

When considering the cost and risks of treatment as well as the lack of sufficient scientific evidences, we believe that PGS should not be offered to RPL group on a routine basis.

\section{ANATOMICAL FACTORS}

\section{Uterine anomalies}

Anatomical defects of the uterus are responsible for 6 to $38 \%$ of cases of recurrent pregnancy loss $(66,161,162)$.
This wide range may be due to differences in diagnostic criteria and techniques. The most common congenital anomaly of the uterus in RPL cases is the subseptate uterus. The proposed mechanisms of the abortion are poor decidualization and placental development due to the avascular uterine septum as well as uncoordinated myometrial contractions caused by increased muscle tissue in the septum ${ }^{(163)}$. The degree of distortion of uterine cavity in subseptate uterus seems to be more important than the length of the septum. The risk of implantation on the septum and thus the risk of miscarriage increase with the degree of uterine cavitydistortion ${ }^{(164)}$. A significant post-operative improvement was detected in the meta-analysis comparing pregnancy outcomes before and after hysteroscopic septoplasty $(163)$.

The second most common congenital uterine anomaly is the arcuate uterus ${ }^{(165)}$. However, the relationship between the arcuate uterus and the pregnancy loss is controversial. Arcuate uterus has been reported to be mostly associated with 2nd trimester losses and premature births ${ }^{(166-168)}$. Some suggest that the only therapeutic approach to prevent the second-trimester losses is cervical cerclage ${ }^{(169)}$.

\section{SUPPORTIVE TREATMENTS}

Although most physicians recommend bed rest for threatened abortion cases, randomized controlled trials indicate that the incidence of pregnancy losses does not decrease with bed rest ${ }^{(173)}$. Beyond this, long-term bed rest is associated with complications such as thromboembolism, weight loss and muscle atrophy $(174,175)$. Women on bed rest have shown to experience denial, anger, loneliness and depression. In addition to these negative emotions, guiltiness has been experienced in patients who had poor compliance with bed rest prior to the miscarriage ${ }^{(176)}$. Although there is no biological explanation, physcological support and or close followup with ultrasound examinations have been seen to reduce the risk of miscarriage to 2-4 times compared with the control groups. The successful pregnancy rate was reported to range from 74 to $86 \%$ in patients who had received supportive treatment $(11,177-180)$. RCOG and ACOG recommend supportive care for unexplained RPL cases and consult the patients regarding the potential for the successful outcome of the subsequent pregnancy without receiving any pharmacological treatment $(139,140)$. 


\section{KAYNAKLAR}

1. Stirrat GM. Recurrent miscarriage. Lancet 1990; 336: 673 5.

2. Farquharson RG, Jauniaux E, and Exalto N. Updated and revised nomenclature for description of early pregnancy events. Hum Reprod 2005; 20: 3008- 11.

3. Nybo Andersen AM, Wohlfahrt J, Christens P, Olsen J, and Melbye M. Maternal age and fetal loss: population based register linkage study. BMJ 2000; 320: 1708- 12.

4. Salat-Baroux J. [Recurrent spontaneous abortions]. Reprod Nutr Dev 1988; 28: 1555- 68

5. Porter TF and Scott JR. Evidence-based care of recurrent miscarriage. Best Pract Res Clin Obstet Gynaecol 2005; 19: 85- 101 .

6. Christiansen OB. Epidemiology of recurrent pregnancy loss, in Carp H., Editor. Recurrent pregnancy loss. Causes, controversies and treatment, Informa healthcare. 2007: 1 - 13.

7. Christiansen O, Astrid M, and Nielsen H. Secondary Recurrent Miscarriage - A Unique Entity with Respect to Etiology and Treatment Current Women's Health Reviews 2006; 2: 119 24

8. Christiansen OB, Pedersen B, Nielsen HS, and Nybo Andersen AM. Impact of the sex of first child on the prognosis in secondary recurrent miscarriage. Hum Reprod 2004; 19: 2946- 51

9. Goldenberg RL, Mayberry SK, Copper RL, Dubard MB, and Hauth JC. Pregnancy outcome following a second-trimester loss. Obstet Gynecol 1993; 81: 444- 6.

10. Oyen N, Skjaerven R, and Irgens LM. Population-based recurrence risk of sudden infant death syndrome compared with other infant and fetal deaths. Am J Epidemiol 1996; 144: 300- 5.

11. Clifford K, Rai R, and Regan L. Future pregnancy outcome in unexplained recurrent first trimester miscarriage. Hum Reprod $1997 ; 12: 387-9$

12. Carp H, Toder V, Aviram A, Daniely M, Mashiach S, and Barkai G. Karyotype of the abortus in recurrent miscarriage. Fertil Steril 2001; 75: 678- 82 .

13. Clark P, Brennand J, Conkie JA, McCall F, Greer IA, and Walker ID. Activated protein $\mathrm{C}$ sensitivity, protein $\mathrm{C}$, protein $\mathrm{S}$ and coagulation in normal pregnancy. Thromb Haemost 1998; 79: 1166- 70.

14. Kjellberg U, Andersson NE, Rosen S, Tengborn L, and Hellgren M. APC resistance and other haemostatic variables during pregnancy and puerperium. Thromb Haemost 1999; 81: $527-$ 31 .

15. Brenner B. Inherited thrombophilia and pregnancy loss. Thromb Haemost 1999; 82: 634- 40.

16. Kupferminc MJ, Eldor A, Steinman N, Many A, Bar-Am A,
Jaffa A, et al. Increased frequency of genetic thrombophilia in women with complications of pregnancy. N Engl J Med 1999; 340: 9- 13.

17. Robertson L, Wu O, Langhorne P, Twaddle S, Clark P, Lowe GD, et al. Thrombophilia in pregnancy: a systematic review. Br J Haematol 2006; 132: 171- 96.

18. Rey E, Kahn SR, David M, and Shrier I. Thrombophilic disorders and fetal loss: a meta-analysis. Lancet 2003; 361: 901-8.

19. Younis JS, Brenner B, Ohel G, Tal J, Lanir N, and Ben-Ami M. Activated protein $\mathrm{C}$ resistance and factor V Leiden mutation can be associated with first-as well as second-trimester recurrent pregnancy loss. Am J Reprod Immunol 2000; 43: 31- 5.

20. Foka ZJ, Lambropoulos AF, Saravelos H, Karas GB, Karavida A, Agorastos T, et al. Factor V leiden and prothrombin G20210A mutations, but not methylenetetrahydrofolate reductase C677T, are associated with recurrent miscarriages. Hum Reprod 2000; 15: 458- 62 .

21. Reznikoff-Etievan MF, Cayol V, Carbonne B, Robert A, Coulet F, and Milliez J. Factor V Leiden and G20210A prothrombin mutations are risk factors for very early recurrent miscarriage. BJOG 2001; 108: 1251- 4 .

22. Pihusch R, Buchholz T, Lohse P, Rubsamen H, Rogenhofer $\mathrm{N}$, Hasbargen U, et al. Thrombophilic gene mutations and recurrent spontaneous abortion: prothrombin mutation increases the risk in the first trimester. Am J Reprod Immunol 2001; 46: $124-31$

23. Finan RR, Tamim H, Ameen G, Sharida HE, Rashid M, and Almawi WY. Prevalence of factor V G1691A (factor V-Leiden) and prothrombin G20210A gene mutations in a recurrent miscarriage population. Am J Hematol 2002; 71: 300- 5.

24. Bellver J, Soares SR, Alvarez C, Munoz E, Ramirez A, Rubio $\mathrm{C}$, et al. The role of thrombophilia and thyroid autoimmunity in unexplained infertility, implantation failure and recurrent spontaneous abortion. Hum Reprod 2008; 23: 278- 84.

25. van Dunne FM, Doggen CJ, Heemskerk M, Rosendaal FR, and Helmerhorst FM. Factor V Leiden mutation in relation to fecundity and miscarriage in women with venous thrombosis. Hum Reprod 2005; 20: 802- 6.

26. Roque H, Paidas MJ, Funai EF, Kuczynski E, and Lockwood CJ. Maternal thrombophilias are not associated with early pregnancy loss. Thromb Haemost 2004; 91: 290- 5.

27. Carp H, Salomon O, Seidman D, Dardik R, Rosenberg N, and Inbal A. Prevalence of genetic markers for thrombophilia in recurrent pregnancy loss. Hum Reprod 2002; 17: 1633- 7.

28. Wilson WA, Gharavi AE, Koike T, Lockshin MD, Branch DW, Piette JC, et al. International consensus statement on preliminary classification criteria for definite antiphospholipid syndrome: report of an international workshop. Arthritis 
Rheum 1999; 42: 1309- 11

29. Dobado-Berrios PM, Lopez-Pedrera C, Velasco F, Aguirre MA, Torres A, and Cuadrado MJ. Increased levels of tissue factor mRNA in mononuclear blood cells of patients with primary antiphospholipid syndrome. Thromb Haemost 1999; 82: 157882

30. Carreras LO and Vermylen JG. "Lupus" anticoagulant and thrombosis--possible role of inhibition of prostacyclin formation. Thromb Haemost 1982; 48: 38- 40

31. Peaceman AM and Rehnberg KA. The effect of immunoglobulin $\mathrm{G}$ fractions from patients with lupus anticoagulant on placental prostacyclin and thromboxane production. Am J Obstet Gynecol 1993; 169: 1403- 6 .

32. Robbins DL, Leung S, Miller-Blair DJ, and Ziboh V. Effect of anticardiolipin/beta2-glycoprotein I complexes on production of thromboxane $\mathrm{A} 2$ by platelets from patients with the antiphospholipid syndrome. J Rheumatol 1998; 25: 51- 6.

33. Wang X, Campos B, Kaetzel MA, and Dedman JR. Annexin $\mathrm{V}$ is critical in the maintenance of murine placental integrity. Am J Obstet Gynecol 1999; 180: 1008- 16

34. Rand JH, Wu XX, Andree HA, Lockwood CJ, Guller S, Scher $\mathrm{J}$, et al. Pregnancy loss in the antiphospholipid-antibody syndrome-a possible thrombogenic mechanism. N Engl J Med 1997; 337: $154-60$

35. Varla-Leftherioti M. Immunobiology of recurrent pregnancy loss, in Carp H.J., Editor. Recurrent Pregnacy Loss Causes, Controversies and Treatment, Informa UK Ltd: UK. 2007: $107-$ 113.

36. Brandt JT, Triplett DA, Alving B, and Scharrer I. Criteria for the diagnosis of lupus anticoagulants: an update. On behalf of the Subcommittee on Lupus Anticoagulant/Antiphospholipid Antibody of the Scientific and Standardisation Committee of the ISTH. Thromb Haemost 1995; 74: 1185- 90.

37. Varla-Leftherioti M. Diagnosis of aPL associated abortions, in Carp H.J., Editor. Recurrent Pregnacy Loss Causes, Controversies and Treatment, informa health care. 2007

38. Coulam CB. Antiphospholipid antibody round table report. Am J Reprod Immunol 2002; 48: 262- 5

39. Shi W, Krilis SA, Chong BH, Gordon S, and Chesterman CN. Prevalence of lupus anticoagulant and anticardiolipin antibodies in a healthy population. Aust N Z J Med 1990; 20: 231- 6.

40. Vila P, Hernandez MC, Lopez-Fernandez MF, and Batlle J. Prevalence, follow-up and clinical significance of the anticardiolipin antibodies in normal subjects. Thromb Haemost 1994; 72: 209- 13

41. Coulam CB, Branch DW, Clark DA, Gleicher N, Kutteh W, Lockshin MD, et al. American Society for Reproductive Immunology report of the Committee for Establishing Criteria for Diagnosis of Reproductive Autoimmune Syndrome. Am J Reprod Immunol 1999; 41: 121- 32.

42. Reece EA, Garofalo J, Zheng XZ, and Assimakopoulos E. Pregnancy outcome. Influence of antiphospholipid antibody titer, prior pregnancy losses and treatment. J Reprod Med 1997; 42: 49- 55.

43. Aoki K, Hayashi Y, Hirao Y, and Yagami Y. Specific antiphospholipid antibodies as a predictive variable in patients with recurrent pregnancy loss. Am J Reprod Immunol 1993; 29: 82- 7 .

44. Kwak JY, Barini R, Gilman-Sachs A, Beaman KD, and Beer AE. Down-regulation of maternal antiphospholipid antibodies during early pregnancy and pregnancy outcome. Am J Obstet Gynecol 1994; 171: 239- 46.

45. Nielsen HS and Christiansen OB. Prognostic impact of anticardiolipin antibodies in women with recurrent miscarriage negative for the lupus anticoagulant. Hum Reprod 2005; 20: 1720- 8.

46. Tulppala M, Viinikka L, and Ylikorkala O. Thromboxane dominance and prostacyclin deficiency in habitual abortion. Lancet $1991 ; 337: 879-81$.

47. Fishman P, Falach-Vaknin E, Sredni B, Meroni PL, Tincani A, Dicker D, et al. Aspirin-interleukin-3 interrelationships in patients with anti-phospholipid syndrome. Am J Reprod Immunol 1996; 35: 80-c4

48. Fishman P, Falach-Vaknin E, Sredni B, Meroni PL, Rudniki C, and Shoenfeld Y. Aspirin modulates interleukin-3 production: additional explanation for the preventive effects of aspirin in antiphospholipid antibody syndrome. J Rheumatol 1995; 22 : 1086- 90 .

49. Cowchock S and Reece EA. Do low-risk pregnant women with antiphospholipid antibodies need to be treated? Organizing Group of the Antiphospholipid Antibody Treatment Trial. Am J Obstet Gynecol 1997; 176: 1099- 100.

50. Tulppala M, Marttunen M, Soderstrom-Anttila V, Foudila T, Ailus K, Palosuo T, et al. Low-dose aspirin in prevention of miscarriage in women with unexplained or autoimmune related recurrent miscarriage: effect on prostacyclin and thromboxane A2 production. Hum Reprod 1997; 12: 1567- 72.

51. Pattison NS, Chamley LW, Birdsall M, Zanderigo AM, Liddell HS, and McDougall J. Does aspirin have a role in improving pregnancy outcome for women with the antiphospholipid syndrome? A randomized controlled trial. Am J Obstet Gynecol 2000; 183: 1008- 12 .

52. Empson M, Lassere M, Craig J, and Scott J. Prevention of recurrent miscarriage for women with antiphospholipid antibody or lupus anticoagulant. Cochrane Database Syst Rev 2005CD 002859 .

53. Laskin CA, Bombardier C, Hannah ME, Mandel FP, Ritchie 
JW, Farewell V, et al. Prednisone and aspirin in women with autoantibodies and unexplained recurrent fetal loss. N Engl J Med 1997; 337: 148- 53

54. Silver RK, MacGregor SN, Sholl JS, Hobart JM, Neerhof MG, and Ragin A. Comparative trial of prednisone plus aspirin versus aspirin alone in the treatment of anticardiolipin antibodypositive obstetric patients. Am J Obstet Gynecol 1993; 169: 1411- 7 .

55. Bates SM, Greer IA, Hirsh J, and Ginsberg JS. Use of antithrombotic agents during pregnancy: the Seventh ACCP Conference on Antithrombotic and Thrombolytic Therapy. Chest 2004; 126 : $627 \mathrm{~S}-644 \mathrm{~S}$

56. Tincani A, Branch W, Levy RA, Piette JC, Carp H, Rai RS, et al. Treatment of pregnant patients with antiphospholipid syndrome. Lupus 2003; 12: 524- 9.

57. Harris WAWaN. Management of antiphospholipid syndrome in pregnancy, in CARP H.J., Editor. Recurrent Pregnancy Loss: Causes, Controversies and Treatment, Informa. 2007: 119- 25

58. Klentzeris LD. The role of endometrium in implantation. Hum Reprod 1997; 12: 170- 5.

59. Wilcox AJ, Baird DD, and Weinberg CR. Time of implantation of the conceptus and loss of pregnancy. N Engl J Med 1999; 340: 1796- 9

60. Li TC. Recurrent miscarriage: principles of management. Hum Reprod 1998; 13: 478- 82.

61. Tulppala M, Bjorses UM, Stenman UH, Wahlstrom T, and Ylikorkala O. Luteal phase defect in habitual abortion: progesterone in saliva. Fertil Steril 1991; 56: 41- 4.

62. Li TC, Dockery P, Rogers AW, and Cooke ID. How precise is histologic dating of endometrium using the standard dating criteria? Fertil Steril 1989; 51: 759- 63.

63. Davis OK, Berkeley AS, Naus GJ, Cholst IN, and Freedman $\mathrm{KS}$. The incidence of luteal phase defect in normal, fertile women, determined by serial endometrial biopsies. Fertil Steril 1989; 51: 582- 6

64. Ogasawara M, Kajiura S, Katano K, Aoyama T, and Aoki K. Are serum progesterone levels predictive of recurrent miscarriage in future pregnancies? Fertil Steril 1997; 68: 806- 9.

65. Jauniaux E, Farquharson RG, Christiansen OB, and Exalto N. Evidence-based guidelines for the investigation and medical treatment of recurrent miscarriage. Hum Reprod 2006; 21 2216- 22.

66. Clifford K, Rai R, Watson H, and Regan L. An informative protocol for the investigation of recurrent miscarriage: preliminary experience of 500 consecutive cases. Hum Reprod 1994; 9: 1328- 32 .

67. Drakeley AJ, Quenby S, and Farquharson RG. Mid-trimester loss--appraisal of a screening protocol. Hum Reprod 1998; 13: $1975-80$

68. Temple R, Aldridge V, Greenwood R, Heyburn P, Sampson M, and Stanley K. Association between outcome of pregnancy and glycaemic control in early pregnancy in type 1 diabetes: population based study. BMJ 2002; 325: 1275- 6 .

69. Rai R, Backos M, Rushworth F, and Regan L. Polycystic ovaries and recurrent miscarriage--a reappraisal. Hum Reprod 2000; 15: $612-5$.

70. Lashen H, Fear K, and Sturdee DW. Obesity is associated with increased risk of first trimester and recurrent miscarriage: matched case-control study. Hum Reprod 2004; 19: 1644- 6.

71. Metwally M, Tuckerman EM, Laird SM, Ledger WL, and Li TC. Impact of high body mass index on endometrial morphology and function in the peri-implantation period in women with recurrent miscarriage. Reprod Biomed Online 2007; 14: 32834.

72. Arredondo F and Noble LS. Endocrinology of recurrent pregnancy loss. Semin Reprod Med 2006; 24: 33- 9.

73. Csapo AI, Pulkkinen MO, and Wiest WG. Effects of luteectomy and progesterone replacement therapy in early pregnant patients. Am J Obstet Gynecol 1973; 115: 759- 65.

74. Haas DM and Ramsey PS. Progestogen for preventing miscarriage. Cochrane Database Syst Rev 2008CD003511.

75. Silver RI, Rodriguez R, Chang TS, and Gearhart JP. In vitro fertilization is associated with an increased risk of hypospadias. J Urol 1999; 161: 1954- 7.

76. Carmichael SL, Shaw GM, Laurent C, Croughan MS, Olney RS, and Lammer EJ. Maternal progestin intake and risk of hypospadias. Arch Pediatr Adolesc Med 2005; 159: 957- 62.

77. Scott JR and Pattison N. Human chorionic gonadotrophin for recurrent miscarriage. Cochrane Database Syst Rev 2000CD 000101.

78. Aoki K, Kajiura S, Matsumoto Y, Ogasawara M, Okada S, Yagami Y, et al. Preconceptional natural-killer-cell activity as a predictor of miscarriage. Lancet 1995; 345: 1340- 2.

79. Ruiz JE, Kwak JY, Baum L, Gilman-Sachs A, Beaman KD, Kim YB, et al. Effect of intravenous immunoglobulin $\mathrm{G}$ on natural killer cell cytotoxicity in vitro in women with recurrent spontaneous abortion. J Reprod Immunol 1996; 31: 125- 41.

80. Emmer PM, Nelen WL, Steegers EA, Hendriks JC, Veerhoek M, and Joosten I. Peripheral natural killer cytotoxicity and CD56(pos)CD16(pos) cells increase during early pregnancy in women with a history of recurrent spontaneous abortion. Hum Reprod 2000; 15: 1163-9.

81. Coulam CB, Goodman C, Roussev RG, Thomason EJ, and Beaman KD. Systemic CD56+ cells can predict pregnancy outcome. Am J Reprod Immunol 1995; 33: 40- 6. 
82. Oksenberg JR, Persitz E, Amar A, and Brautbar C. Maternalpaternal histocompatibility: lack of association with habitual abortions. Fertil Steril 1984; 42: 389- 95.

83. Jazwinska EC, Kilpatrick DC, Smart GE, and Liston WA. Feto-maternal HLA compatibility does not have a major influence on human pregnancy except for lymphocytotoxin production. Clin Exp Immunol 1987; 69: 116- 22.

84. Christiansen OB, Riisom K, Lauritsen JG, and Grunnet N. No increased histocompatibility antigen-sharing in couples with idiopathic habitual abortions. Hum Reprod 1989; 4: 160- 2.

85. Eroglu G, Betz G, and Torregano C. Impact of histocompatibility antigens on pregnancy outcome. Am J Obstet Gynecol 1992; 166: $1364-9$

86. Christiansen OB, Nybo Andersen AM, Bosch E, Daya S, Delves PJ, Hviid TV, et al. Evidence-based investigations and treatments of recurrent pregnancy loss. Fertil Steril 2005; 83: 821- 39.

87. Moffett A and Loke C. Immunology of placentation in eutherian mammals. Nat Rev Immunol 2006; 6: 584- 94.

88. Ellis SA, Palmer MS, and McMichael AJ. Human trophoblast and the choriocarcinoma cell line BeWo express a truncated HLA Class I molecule. J Immunol 1990; 144: 731- 5.

89. Menier C, Riteau B, Dausset J, Carosella ED, and Rouas-Freiss N. HLA-G truncated isoforms can substitute for HLA-G1 in fetal survival. Hum Immunol 2000; 61: 1118- 25.

90. Pfeiffer KA, Fimmers R, Engels G, van der Ven H, and van der Ven K. The HLA-G genotype is potentially associated with idiopathic recurrent spontaneous abortion. Mol Hum Reprod 2001; 7: 373-8.

91. Aldrich CL, Stephenson MD, Karrison T, Odem RR, Branch DW, Scott JR, et al. HLA-G genotypes and pregnancy outcome in couples with unexplained recurrent miscarriage. Mol Hum Reprod 2001; 7: 1167- 72 .

92. Hviid TV, Hylenius S, Hoegh AM, Kruse C, and Christiansen OB. HLA-G polymorphisms in couples with recurrent spontaneous abortions. Tissue Antigens 2002; 60: 122- 32.

93. Christiansen OB, Ring M, Rosgaard A, Grunnet N, and Gluud C. Association between HLA-DR1 and -DR3 antigens and unexplained repeated miscarriage. Hum Reprod Update 1999; 5: $249-55$.

94. Pociot F, Briant L, Jongeneel CV, Molvig J, Worsaae H, Abba $\mathrm{M}$, et al. Association of tumor necrosis factor (TNF) and class II major histocompatibility complex alleles with the secretion of TNF-alpha and TNF-beta by human mononuclear cells: a possible link to insulin-dependent diabetes mellitus. Eur J Immunol 1993; 23: 224- 31.

95. Szekeres-Bartho J. Immunological relationship between the mother and the fetus. Int Rev Immunol 2002; 21: 471- 95

96. Wegmann TG, Lin H, Guilbert L, and Mosmann TR. Bidirectional cytokine interactions in the maternal-fetal relationship: is successful pregnancy a TH2 phenomenon? Immunol Today 1993; 14: 353- 6 .

97. Makhseed M, Raghupathy R, Azizieh F, Omu A, Al-Shamali E, and Ashkanani L. Th1 and Th2 cytokine profiles in recurrent aborters with successful pregnancy and with subsequent abortions. Hum Reprod 2001; 16: 2219- 26.

98. Raghupathy R. Th1-type immunity is incompatible with successful pregnancy. Immunol Today 1997; 18: 478- 82

99. Kwak-Kim JY, Chung-Bang HS, Ng SC, Ntrivalas EI, Mangubat $\mathrm{CP}$, Beaman $\mathrm{KD}$, et al. Increased T helper 1 cytokine responses by circulating $\mathrm{T}$ cells are present in women with recurrent pregnancy losses and in infertile women with multiple implantation failures after IVF. Hum Reprod 2003; 18: 767- 73.

100. Szekeres-Bartho J, Weill BJ, Mike G, Houssin D, and Chaouat G. Progesterone receptors in lymphocytes of liver-transplanted and transfused patients. Immunol Lett 1989; 22: 259- 61.

101. Szekeres-Bartho J, Varga P, and Pejtsik B. ELISA test for the detection of an immunological blocking factor in human pregnancy serum. J Reprod Immunol 1989; 16: 19- 29.

102. Druckmann R and Druckmann MA. Progesterone and the immunology of pregnancy. J Steroid Biochem Mol Biol 2005; 97: 389- 96

103. Piccinni MP, Giudizi MG, Biagiotti R, Beloni L, Giannarini L, Sampognaro S, et al. Progesterone favors the development of human T helper cells producing Th2-type cytokines and promotes both IL-4 production and membrane CD30 expression in established Th1 cell clones. J Immunol 1995; 155: 128- 33.

104. Choi BC, Polgar K, Xiao L, and Hill JA. Progesterone inhibits in-vitro embryotoxic Th1 cytokine production to trophoblast in women with recurrent pregnancy loss. Hum Reprod 2000; 15 Suppl 1: 46- 59.

105. Check JH. Th1 and Th2 cytokine profiles in recurrent aborters may merely reflect the progesterone status. Hum Reprod 2002; 17: 1669-70; author reply 1670- 1 .

106. King A, Jokhi PP, Burrows TD, Gardner L, Sharkey AM, and Loke YW. Functions of human decidual NK cells. Am J Reprod Immunol 1996; 35: 258- 60 .

107. Quenby S, Bates M, Doig T, Brewster J, Lewis-Jones DI, Johnson PM, et al. Pre-implantation endometrial leukocytes in women with recurrent miscarriage. Hum Reprod 1999; 14 : 2386- 91 .

108. Quenby S, Kalumbi C, Bates M, Farquharson R, and Vince G. Prednisolone reduces preconceptual endometrial natural killer cells in women with recurrent miscarriage. Fertil Steril 2005; 84: 980- 4 .

109. Clifford K, Flanagan AM, and Regan L. Endometrial CD56+ natural killer cells in women with recurrent miscarriage: a 
histomorphometric study. Hum Reprod 1999; 14: 2727- 30.

110. Wilson R, McInnes I, Leung B, McKillop JH, and Walker JJ. Altered interleukin 12 and nitric oxide levels in recurrent miscarriage. Eur J Obstet Gynecol Reprod Biol 1997; 75: 211 4.

111. Yui J, Garcia-Lloret M, Wegmann TG, and Guilbert LJ. Cytotoxicity of tumour necrosis factor-alpha and gammainterferon against primary human placental trophoblasts. Placenta 1994; 15: 819- 35

112. Hayakawa S, Karasaki-Suzuki M, Itoh T, Ishii M, Kanaeda T, Nagai N, et al. Effects of paternal lymphocyte immunization on peripheral Th1/Th2 balance and TCR V beta and V gamma repertoire usage of patients with recurrent spontaneous abortions. Am J Reprod Immunol 2000; 43: 107- 15.

113. Ntrivalas EI, Kwak-Kim JY, Gilman-Sachs A, Chung-Bang $\mathrm{H}, \mathrm{Ng} \mathrm{SC}$, Beaman KD, et al. Status of peripheral blood natural killer cells in women with recurrent spontaneous abortions and infertility of unknown aetiology. Hum Reprod 2001; 16 : 855- 61

114. Yamada H, Morikawa M, Kato EH, Shimada S, Kobashi G, and Minakami H. Pre-conceptional natural killer cell activity and percentage as predictors of biochemical pregnancy and spontaneous abortion with normal chromosome karyotype. Am J Reprod Immunol 2003; 50: 351- 4.

115. Rai R, Sacks G, and Trew G. Natural killer cells and reproductive failure--theory, practice and prejudice. Hum Reprod 2005; 20: $1123-6$.

116. Shimada S, Kato EH, Morikawa M, Iwabuchi K, Nishida R, Kishi R, et al. No difference in natural killer or natural killer T-cell population, but aberrant T-helper cell population in the endometrium of women with repeated miscarriage. Hum Reprod 2004; 19: 1018- 24.

117. Michimata T, Ogasawara MS, Tsuda H, Suzumori K, Aoki K, Sakai M, et al. Distributions of endometrial NK cells, B cells, T cells, and Th2/Tc2 cells fail to predict pregnancy outcome following recurrent abortion. Am J Reprod Immunol 2002; 47: 196- 202 .

118. Guimond MJ, Luross JA, Wang B, Terhorst C, Danial S, and Croy BA. Absence of natural killer cells during murine pregnancy is associated with reproductive compromise in TgE26 mice. Biol Reprod 1997; 56: 169- 79

119. Szekeres-Bartho J, Par G, Dombay G, Smart YC, and Volgyi $Z$. The antiabortive effect of progesterone-induced blocking factor in mice is manifested by modulating NK activity. Cell Immunol 1997; 177: 194- 9.

120. Faust Z, Laskarin G, Rukavina D, and Szekeres-Bartho J. Progesterone-induced blocking factor inhibits degranulation of natural killer cells. Am J Reprod Immunol 1999; 42: 71 -
5.

121. Kelemen K, Bognar I, Paal M, and Szekeres-Bartho J. A progesterone-induced protein increases the synthesis of asymmetric antibodies. Cell Immunol 1996; 167: 129- 34.

122. Li D, Li C, and Zhu Y. [Comparative study of the third party and paternal leukocyte immunization in recurrent spontaneous abortion of lowered maternal-fetal immuno-recognition]. Zhonghua Fu Chan Ke Za Zhi 1998; 33: 597- 600.

123. Ito $\mathrm{K}$, Tanaka $\mathrm{T}$, Tsutsumi $\mathrm{N}$, Obata $\mathrm{F}$, and Kashiwagi $\mathrm{N}$. Possible mechanisms of immunotherapy for maintaining pregnancy in recurrent spontaneous aborters: analysis of anti-idiotypic antibodies directed against autologous T-cell receptors. Hum Reprod 1999; 14: 650- 5.

124. Prigoshin N, Tambutti ML, Redal MA, Gorgorza S, Lancuba SM, Nicholson R, et al. Microchimerism and blocking activity in women with recurrent spontaneous abortion (RSA) after alloimmunization with the partner's lymphocytes. J Reprod Immunol 1999; 44: 41- 54.

125. Pandey MK, Thakur S, and Agrawal S. Lymphocyte immunotherapy and its probable mechanism in the maintenance of pregnancy in women with recurrent spontaneous abortion. Arch Gynecol Obstet 2004; 269: 161- 72.

126. Porter TF, LaCoursiere Y, and Scott JR. Immunotherapy for recurrent miscarriage. Cochrane Database Syst Rev 2006CD 000112 .

127. Kwak JY, Kwak FM, Ainbinder SW, Ruiz AM, and Beer AE. Elevated peripheral blood natural killer cells are effectively downregulated by immunoglobulin $\mathrm{G}$ infusion in women with recurrent spontaneous abortions. Am J Reprod Immunol 1996; 35: $363-9$.

128. Ruiz JE, Kwak JY, Baum L, Gilman-Sachs A, Beaman KD, Kim YB, et al. Intravenous immunoglobulin inhibits natural killer cell activity in vivo in women with recurrent spontaneous abortion. Am J Reprod Immunol 1996; 35: 370- 5.

129. Samuelsson A, Towers TL, and Ravetch JV. Anti-inflammatory activity of IVIG mediated through the inhibitory Fc receptor. Science 2001; 291: 484- 6 .

130. Crow AR, Song S, Semple JW, Freedman J, and Lazarus AH. IVIg inhibits reticuloendothelial system function and ameliorates murine passive-immune thrombocytopenia independent of anti-idiotype reactivity. Br J Haematol 2001; 115: 679- 86.

131. Lutz HU, Stammler P, Jelezarova E, Nater M, and Spath PJ. High doses of immunoglobulin $\mathrm{G}$ attenuate immune aggregatemediated complement activation by enhancing physiologic cleavage of C3b in C3bn-IgG complexes. Blood 1996; 88: 184- 93.

132. Christiansen OB, Mathiesen O, Lauritsen JG, and Grunnet N. Intravenous immunoglobulin treatment of women with multiple 
miscarriages. Hum Reprod 1992; 7: 718- 22.

133. Thornton CA and Ballow M. Safety of intravenous immunoglobulin. Arch Neurol 1993; 50: 135- 6

134. De Braekeleer M and Dao TN. Cytogenetic studies in couples experiencing repeated pregnancy losses. Hum Reprod 1990; 5: $519-28$

135. Simpson JL, Meyers CM, Martin AO, Elias S, and Ober C. Translocations are infrequent among couples having repeated spontaneous abortions but no other abnormal pregnancies. Fertil Steril 1989; 51: 811- 4 .

136. Boue A and Gallano P. A collaborative study of the segregation of inherited chromosome structural rearrangements in 1356 prenatal diagnoses. Prenat Diagn 1984; 4 Spec No: 45- 67.

137. Carp H, Guetta E, Dorf H, Soriano D, Barkai G, and Schiff E. Embryonic karyotype in recurrent miscarriage with parental karyotypic aberrations. Fertil Steril 2006; 85: 446- 50.

138. Carp H, Feldman B, Oelsner G, and Schiff E. Parental karyotype and subsequent live births in recurrent miscarriage. Fertil Steril 2004; 81: 1296- 301

139. ACOG, Management of recurrent early pregnancy loss, ACOG practice bulletin. 2001, American College of Obstetricians and Gynecologists, Washington, DC.

140. RCOG, The Management of Recurrent Miscarriage. 2003 , RCOG: UK.

141. Goddijn M and Leschot NJ. Genetic aspects of miscarriage. Baillieres Best Pract Res Clin Obstet Gynaecol 2000; 14: 855 65.

142. Simon C, Rubio C, Vidal F, Gimenez C, Moreno C, Parrilla $\mathrm{JJ}$, et al. Increased chromosome abnormalities in human preimplantation embryos after in-vitro fertilization in patients with recurrent miscarriage. Reprod Fertil Dev 1998; 10: 87 92

143. Vidal F, Gimenez C, Rubio C, Simon C, Pellicer A, Santalo $\mathrm{J}$, et al. FISH preimplantation diagnosis of chromosome aneuploidy in recurrent pregnancy wastage. J Assist Reprod Genet 1998; $15: 310-3$

144. Stephenson MD, Awartani KA, and Robinson WP. Cytogenetic analysis of miscarriages from couples with recurrent miscarriage: a case-control study. Hum Reprod 2002; 17: 446- 51.

145. Sullivan AE, Silver RM, LaCoursiere DY, Porter TF, and Branch DW. Recurrent fetal aneuploidy and recurrent miscarriage. Obstet Gynecol 2004; 104: 784- 8.

146. Ogasawara M, Aoki K, Okada S, and Suzumori K. Embryonic karyotype of abortuses in relation to the number of previous miscarriages. Fertil Steril 2000; 73: 300- 4.

147. ACOG. Management of early recurrent pregnancy loss. Int J Gynecol Obstet 2002; 78: 178- 90.

148. Pathologists RCo (2005) Fetal and Perinatal Pathology: Report of a Joint Working Party.

149. Boue J, Bou A, and Lazar P. Retrospective and prospective epidemiological studies of 1500 karyotyped spontaneous human abortions. Teratology 1975; 12: 11- 26.

150. Hassold TJ. A cytogenetic study of repeated spontaneous abortions. Am J Hum Genet 1980; 32: 723- 30.

151. Sorokin Y, Johnson MP, Uhlmann WR, Zador IE, Drugan A, Koppitch FC, 3rd, et al. Postmortem chorionic villus sampling: correlation of cytogenetic and ultrasound findings. Am J Med Genet 1991; 39: 314- 6 .

152. Stern JJ, Dorfmann AD, Gutierrez-Najar AJ, Cerrillo M, and Coulam CB. Frequency of abnormal karyotypes among abortuses from women with and without a history of recurrent spontaneous abortion. Fertil Steril 1996; 65: 250- 3.

153. Ferro J, Martinez MC, Lara C, Pellicer A, Remohi J, and Serra V. Improved accuracy of hysteroembryoscopic biopsies for karyotyping early missed abortions. Fertil Steril 2003; 80: 1260- 4

154. Rubio C, Simon C, Vidal F, Rodrigo L, Pehlivan T, Remohi $\mathrm{J}$, et al. Chromosomal abnormalities and embryo development in recurrent miscarriage couples. Hum Reprod 2003; 18: 1828.

155. Munne S, Chen S, Fischer J, Colls P, Zheng X, Stevens J, et al. Preimplantation genetic diagnosis reduces pregnancy loss in women aged 35 years and older with a history of recurrent miscarriages. Fertil Steril 2005; 84: 331- 5.

156. Platteau P, Staessen C, Michiels A, Van Steirteghem A, Liebaers I, and Devroey P. Preimplantation genetic diagnosis for aneuploidy screening in patients with unexplained recurrent miscarriages. Fertil Steril 2005; 83: 393-7; quiz 525- 6 .

157. Michiels A, Van Assche E, Liebaers I, Van Steirteghem A, and Staessen C. The analysis of one or two blastomeres for PGD using fluorescence in-situ hybridization. Hum Reprod 2006; 21: 2396- 402

158. DeUgarte CM, Li M, Surrey M, Danzer H, Hill D, and DeCherney AH. Accuracy of FISH analysis in predicting chromosomal status in patients undergoing preimplantation genetic diagnosis. Fertil Steril 2008; 90: 1049- 54.

159. Bielanska M, Tan SL, and Ao A. Chromosomal mosaicism throughout human preimplantation development in vitro: incidence, type, and relevance to embryo outcome. Hum Reprod 2002; 17: 413-9.

160. Baart EB, Martini E, van den Berg I, Macklon NS, Galjaard RJ, Fauser BC, et al. Preimplantation genetic screening reveals a high incidence of aneuploidy and mosaicism in embryos from young women undergoing IVF. Hum Reprod 2006; 21 : 223- 33 .

161. Makino T, Hara T, Oka C, Toyoshima K, Sugi T, Iwasaki K, 
et al. Survey of 1120 Japanese women with a history of recurrent spontaneous abortions. Eur J Obstet Gynecol Reprod Biol 1992; 44: 123- 30 .

162. Acien P. Uterine anomalies and recuurent miscarriage. Infertil Reprod. Med Clin N Amer. 1996; 7: 698- 719.

163. Homer HA, Li TC, and Cooke ID. The septate uterus: a review of management and reproductive outcome. Fertil Steril 2000; 73: $1-14$.

164. Salim R, Regan L, Woelfer B, Backos M, and Jurkovic D. A comparative study of the morphology of congenital uterine anomalies in women with and without a history of recurrent first trimester miscarriage. Hum Reprod 2003; 18: 162- 6.

165. Aslam Ja. 3D Ultrasound in Obstetrics and Gynaecolgy 1998; 27- 9 .

166. Raga F, Bauset C, Remohi J, Bonilla-Musoles F, Simon C, and Pellicer A. Reproductive impact of congenital Mullerian anomalies. Hum Reprod 1997; 12: 2277- 81.

167. Acien P. Reproductive performance of women with uterine malformations. Hum Reprod 1993; 8: 122- 6.

168. Woelfer B, Salim R, Banerjee S, Elson J, Regan L, and Jurkovic

D. Reproductive outcomes in women with congenital uterine anomalies detected by three-dimensional ultrasound screening. Obstet Gynecol 2001; 98: 1099- 103.

169. Golan A, Langer R, Wexler S, Segev E, Niv D, and David MP. Cervical cerclage--its role in the pregnant anomalous uterus. Int J Fertil 1990; 35: 164- 70.

170. Bajekal $\mathrm{N}$ and Li TC. Fibroids, infertility and pregnancy wastage. Hum Reprod Update 2000; 6: 614- 20.

171. Varasteh NN, Neuwirth RS, Levin B, and Keltz MD. Pregnancy rates after hysteroscopic polypectomy and myomectomy in infertile women. Obstet Gynecol 1999; 94: 168- 71.
172. Ventolini G, Zhang M, and Gruber J. Hysteroscopy in the evaluation of patients with recurrent pregnancy loss: a cohort study in a primary care population. Surg Endosc 2004; 18 : 1782- 4 .

173. Aleman A, Althabe F, Belizan J, and Bergel E. Bed rest during pregnancy for preventing miscarriage. Cochrane Database Syst Rev 2005 CD003576.

174. Maloni JA, Chance B, Zhang C, Cohen AW, Betts D, and Gange SJ. Physical and psychosocial side effects of antepartum hospital bed rest. Nurs Res 1993; 42: 197- 203.

175. Kovacevich GJ, Gaich SA, Lavin JP, Hopkins MP, Crane SS, Stewart J, et al. The prevalence of thromboembolic events among women with extended bed rest prescribed as part of the treatment for premature labor or preterm premature rupture of membranes. Am J Obstet Gynecol 2000; 182: 1089- 92.

176. Maloni JA, Brezinski-Tomasi JE, and Johnson LA. Antepartum bed rest: effect upon the family. J Obstet Gynecol Neonatal Nurs 2001; 30: 165- 73.

177. Stray-Pedersen B and Stray-Pedersen S. Etiologic factors and subsequent reproductive performance in 195 couples with a prior history of habitual abortion. Am J Obstet Gynecol 1984; 148: $140-6$

178. Tupper $\mathrm{C}$ and Weil RJ. The problem of spontaneous abortion. IX. The treatment of habitual aborters by psychotherapy. Am J Obstet Gynecol 1962; 83: 421- 4.

179. Brigham SA, Conlon C, and Farquharson RG. A longitudinal study of pregnancy outcome following idiopathic recurrent miscarriage. Hum Reprod 1999; 14: 2868- 71.

180. Liddell HS, Pattison NS, and Zanderigo A. Recurrent miscarriage-outcome after supportive care in early pregnancy. Aust N Z J Obstet Gynaecol 1991; 31: 320- 2. 